\title{
TINJAUAN PERBANDINGAN TEBAL PERKERASAN JALAN LENTUR DENGAN METODE BINA MARGA 1987 DENGAN MANUAL DESAIN PERKERASAN JALAN 2017 DI JALAN LINTAS LABUAN BAJO-LEMBOR
}

\author{
Angelina Leonora Vera ${ }^{1}$, Hermansyah ${ }^{2^{*}}$, dan Dedy Dharmawansyah ${ }^{3}$ \\ 1,2,3 Teknik Sipil Universitas Teknologi Sumbawa \\ *E-mail: hermansyah@uts.ac.id
}

\begin{abstract}
Abstrak
Jalan lintas Labuan Bajo-Lembor merupakan jalan Nasional yang menghubungkan Kabupaten Labuan Bajo dan Lembor. Jalan tersebut banyak dilalui oleh kendaraan berat diatas 10 ton mengakibatkan terjadi kerusakan pada bagian jalan. Perlu dilakukan perencanaan tebal perkerasan jalan dengan menyesuaikan geometri jalan dan intensitas curah hujan di daerah tersebut. Penelitian ini bertujuan merencanakan tebal perkerasan jalan menggunakan metode Bina Marga 1987 dan Manual Desain Perkerasan Jalan 2017. Hasil perhitungan diperoleh tebal lapisan total dengan metode Bina Marga 1987 untuk umur rencana 5, 10 dan 20 tahun sebesar 48,5 cm, $53.5 \mathrm{~cm}$ dan $70.30 \mathrm{~cm}$, sedangkan metode Manual Desain Perkerasan Jalan 2017 untuk umur rencana 5, 10 dan 20 tahun sebesar $70 \mathrm{~cm}, 67 \mathrm{~cm}$ dan $74 \mathrm{~cm}$. Perencanaan tebal perkerasan dengan metode Bina Marga 1987 jauh lebih tipis sehingga dapat dikatakan metode Bina Marga 1987 lebih baik dibandingkan metode Manual Desain Perkerasan Jalan 2017.
\end{abstract}

Kata kunci: Perkerasan Lentur, Bina Marga 1987, MDP 2017

\section{PENDAHULUAN}

Keberadaan jalan raya sangat diperlukan untuk menunjang laju pertumbuhan ekonomi, pertanian dan sektor lainya. Hal ini dikarenakan jalan merupakan suatu sarana transportasi yang sangat penting untuk melayani pergerakan manusia dan atau barang dari suatu tempat ke tempat lain secara aman, nyaman dan ekonomis, maka dari itu perlu dilakukan perencanaan terkait perkerasan jalan.

Perencanaan perkerasan jalan yang tidak sesuai sering kali menjadi penyebab utama dari kerusakan jalan. Kerusakan jalan biasanya disebabkan oleh beberapa faktor misalnya air hujan, akibat beban roda kendaraan berat yang melewati jalan tersebut, kondisi muka air tanah yang tinggi, akibat dari salah pada waktu pelaksanaan dan juga bisa diakibatkan kesalahan pada waktu perencanaan (Bachanas, 2009). Kerusakan seperti itu tidak dipungkiri dapat terjadi pada jalan di beberapa daerah terlebih khusus untuk jalan lintas Labuan Bajo-Lembor.

Jalan Labuan Bajo-Lembor merupakan jalan utama yang menghubungkan Labuan Bajo dan Lembor. Jalan Labuan Bajo-Lembor terletak di Kabupaten Manggarai Barat Pulau Flores, Provinsi Nusa Tenggara Timur (NTT) (Gambar 2.). Jalan Labuan Bajo-Lembor merupakan jalan yang masuk dalam kategori jalan nasional. Karena merupakan jalan nasional maka jalan ini harus diminimalisir dari berbagai bentuk kerusakan jalan.

Untuk meminimalisir terjadinya kerusakan pada jalan lintas Labuan BajoLembor perlu dilakukan perencanaan terkait tebal perkerasan jalan yang sesuai dengan kondisi tanah dasar dari jalan tersebut. Perencaaan yang dilakukakan adalah perencanaan tebal perkerasan lentur. Pemilihan jenis perkerasan lentur karena jenis perkerasan ini mampu mendukung beban lalu lintas tanpa adanya perubahan bentuk pada permukaan, melindungi tanah dasar dari air, memperkecil kemungkinan pelepasan butir pada permukaan, memberikan tekstur permukaan yang memadai dan lentur terhadap lapis tanah dasar.

Perencanaan tebal perkerasan lentur dilakukan dengan menggunakan dua metode sebagai perbandingan untuk mengetahui tebal perkerasan dengan metode mana yang jauh lebih ekonomis. Metode yang digunakan adalah metode Bina Marga 1987 dan Manual Desain Perkerasan Jalan 2017.

\section{Tujuan Penelitian}

Tujuan dilakukan penelitian ini adalah untuk mengetahui perbandingan tebal 
perkerasan jalan pada jalan lintas Labuan BajoLembor menggunakan metode Bina Marga 1987 dan Manual Desain Perkerasan Jalan Tahun 2017.

\section{METODE PENELITIAN}

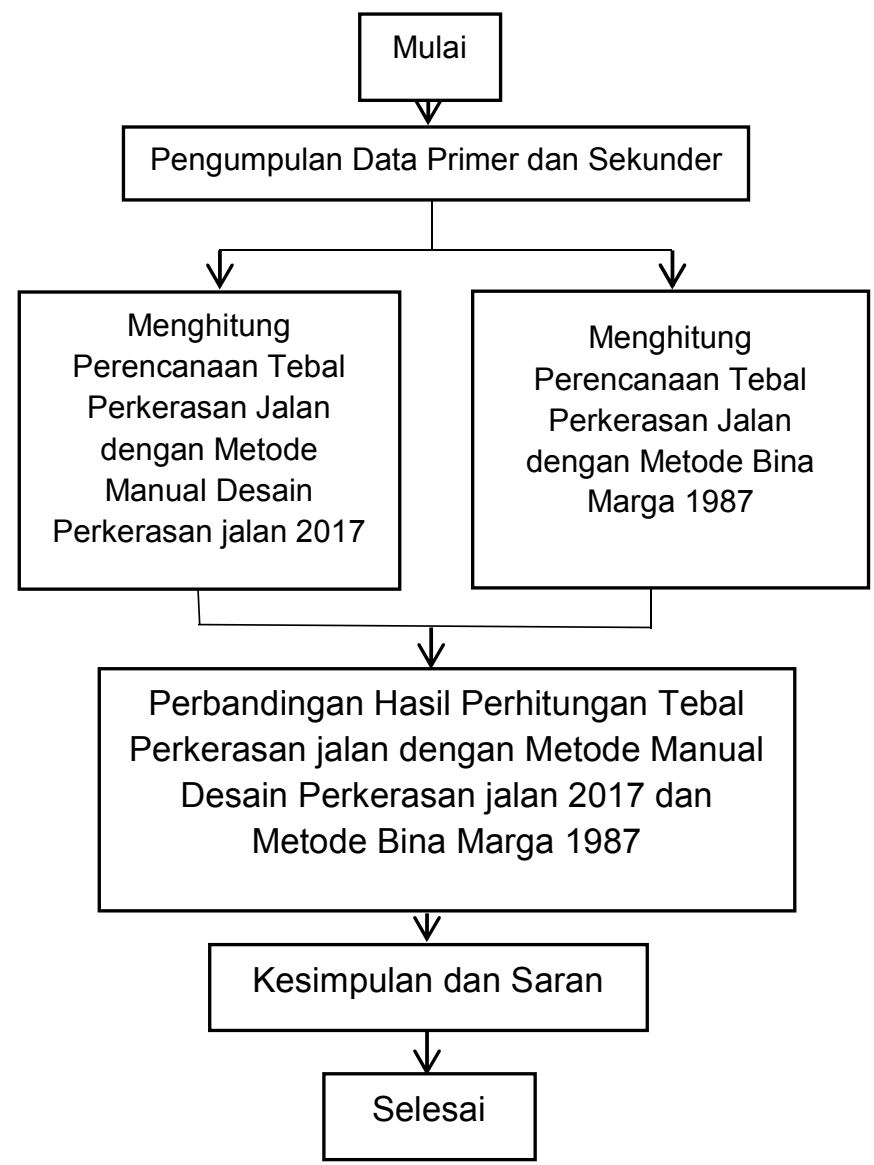

Gambar 1. Diagram Alir Penelitian

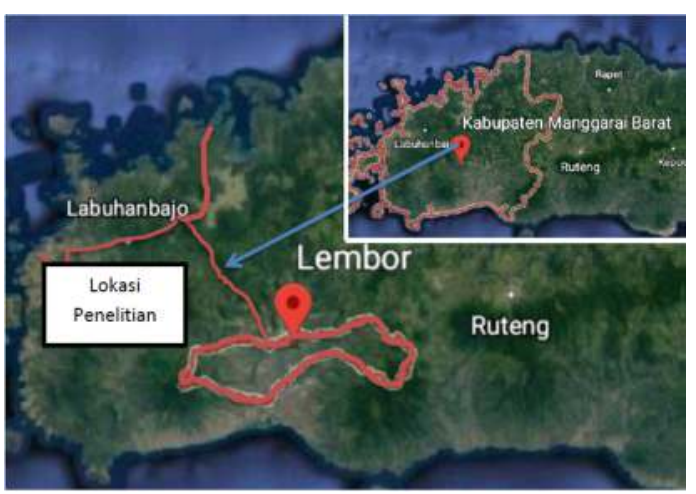

Gambar 2. Lokasi Survei Sumber: Googleearth Peta Jalan Lintas Labuan Bajo-Lembor

\section{HASIL DAN PEMBAHASAN}

Jalan Lintas Labuan Bajo - Lembor menurut SK Menteri Pekerjaan Umum no 631/KPTS/M/2009 merupakan jalan nasional. Dalam penelitian ini perkerasan jalan direncanakan untuk jalan baru 1 jalur, 2 lajur, 2 arah, hal ini dikarenakan kondisi eksisting tempat jalan akan dibangun hanya memungkinkan untuk dibangun 1 jalur 2 lajur, 2 arah dengan lebar total rencana $7 \mathrm{~m}$. Berdasarkan kondisi tempat jalan akan dibangun melayani dan menghubungkan kotakota antara pusat kegiatan wilayah (Labuan Bajo) dan pusat kegiatan lokal (Lembor) jalan masuk dalam kategori jalan kolektor. Menyesuaikan dengan total LHR tahun awal sebesar 2111 jalan masuk dalam kategori kelas II B (1500 - 8000).

Data LHR Kementerian Pekerjaan Umum Kota Jaya Pura tahun 2015 yang dijadikan sebagai LHR tahun rencana (2018) dalam penelitian ini. Penggunaan data LHR jalan lintas Sentani - Warumbain Kota Jaya Pura sebagai data LHR untuk perencanaan jalan baru pada jalan lintas Labuan Bajo Lembor didasarkan pada kesamaan status jalan yaitu sama-sama jalan nasional dan berdasarkan fungsi jalannya merupakan jalan kolektor.

Tabel 1. Lalu Lintas Harian Rata-Rata Rencana 2015 (2 arah)

\begin{tabular}{lc}
\hline Kendaraan & LHR \\
\hline Sepeda Motor & 1329 \\
Mobil & 517 \\
Bus Sedang 5.4 ton & 20 \\
Truk Kecil 2as 8.16 Ton & 123 \\
Truk Besar 2as 15 Ton & 87 \\
Truk Besar 3as 25 Ton & 35 \\
\hline
\end{tabular}

Jalan lintas Labuan Bajo-Lembor pada dasarnya sudah memiliki perkerasan jalan berupa jalan aspal yang mengalami kerusakan di beberapa bagian badan jalan. Kerusakan jalan yang dimaksud seperti jalan yang retakretak dan berlubang. Kondisi jalan sangat tidak nyaman dan aman, kondisi jalan yang demikian membuat pengendara sangat berhati-hati ketika melewati jalan tersebut. Keruskan jalan sendiri salah satunya bisa di sebabkan oleh ketebalan dari perkerasan jalan yang tidak sesuai dengan kondisi tanah dan beban yang diterima. Maka dari itu dalam penelitian ini penulis mencoba menghitung tebal perkerasan jalan dengan metode Bina Marga 1987 dan Manual Desain Perkerasan jalan 2017.

\section{Perhitungan Tebal Perkerasan Jalan Metode Bina Marga 1987}

Berdasarkan bagan alir dari Metode Perencanaan Tebal Perkerasan Lentur Bina Marga 1987 dapat dibuat langkah-langkah perencanaan dan perhitungan tebal perkerasan sebagai berikut:

\section{Menentukan Umur Rencana}

Umur rencana (UR) adalah jumlah 


\section{Judul Artikel Jurnal \\ Nama Penulis ${ }^{1 *}$, Nama Penulis ${ }^{2}$, dan Nama Penulis ${ }^{3}$}

waktu dalam tahun dihitung sejak jalan tersebut mulai dibuka sampai saat diperlukan perbaikan berat atau dianggap perlu untuk diberi lapis permukaan yang baru, untuk perkerasan lentur umur rencana pada penelitian ini digunakan umur rencana 5 tahun, 10 tahun dan 20 tahun Untuk lebih jelasnya dapat dilihat pada Tabel 2.

Tabel 2. Tahun Perencanan Tebal Perkerasan Jalan

\begin{tabular}{ll}
\hline Keterangan & Tahun \\
\hline Perencanaan & 2018 \\
Pelaksanaan & 2018 \\
Jalan Pertama Kali Dibuka & 2019 \\
Umur Rencana 5 Tahun & $2019-2024$ \\
Umur Rencana 10 Tahun & $2019-2029$ \\
Umur Rencana 20 Tahun & $2019-2039$ \\
\hline
\end{tabular}

\section{Data Lalu Lintas Awal}

Data lalu lintas adalah jumlah jenis kendaraan yang hendak memakai jalan, yang sifatnya beraneka ragam, bervariasi baik ukuran, berat total, konfigurasi dan beban sumbu. Oleh karna itu data lalu lintas umumnya dikelompokkan atas beberapa kelompok yang masing-masing kelompok diwakili oleh satu jenis kendaraan. Seperti, mobil, bus, truk, dll. Khusus untuk sepeda motor tidak dihitung karena tidak mempunyai susunan gandar dan tidak berpengaruh pada perkerasan.

\section{Perhitungan Intesitas Pertumbuhan Ialu Lintas}

Pertumbuhan lalu lintas selama umur rencana, antara lain dipengaruhi atau berdasarkan atas analisa ekonomi dan sosial daerah tersebut yang menyebabkan kenaikan jumlah kendaraan setiap tahunnya. Untuk menghitung presentase pertumbuhan lalu lintas suatu daerah tahun ke $\mathrm{n}$ dapat dilihat dari jumlah kendaraan tahun awal 2016 dan tahun akhir 2017.

Tabel 3. Jumlah Kendaraan Kabupaten Manggarai Barat (2017)

\begin{tabular}{lc}
\hline Jenis Kendaraan & Jumlah Kendaraan \\
\hline Sedan/Jeep & 728 \\
Mikro Bus & 25 \\
Truk sedang & 734 \\
Sepeda Motor & 8960 \\
Jumlah & 10447 \\
\hline Sumber: Samsat Kabupaten Manggarai
\end{tabular}

Tabel 4. Jumlah Kendaraan Kabupaten Manggarai Barat (2018)

\begin{tabular}{lc}
\hline Jenis Kendaraan & Jumlah Kendaraan \\
\hline Sedan/Jeep & 852 \\
Mikro Bus & 25 \\
Truk sedang & 973 \\
Sepeda Motor & 10410 \\
Jumlah & 12260 \\
\hline Sumber: Samsat Kabupaten Manggarai Barat
\end{tabular}

Berdasarkan Tabel 3. dan Tabel 4. didapatkan jumlah kendaraan tahun 2017 (tahun awal) sebesar 10447 dan pada tahun 2018 (tahun akhir) sebesar 12260 kendaraan.

$$
\begin{gathered}
i(2017-2018)=\left(\frac{\mathbf{b}}{\mathbf{a}}\right)^{\frac{1}{n}}-1 \times 100 \% \\
i=\left(\frac{\mathbf{1 2 2 6 0}}{\mathbf{1 0 4 4 7}}\right)^{\frac{1}{n}}-1 \times 100 \% \\
\quad i=8.3 \%=0.083
\end{gathered}
$$

Dimana:

$$
\begin{array}{ll}
\mathrm{a} & =\text { Jumlah kendaraan tahun awal } \\
\mathrm{b} & =\text { Jumlah kendaraan tahun akhir } \\
\mathrm{n} & =\text { Jumlah tahun }
\end{array}
$$

\section{Menentukan Angka Ekivalen (E) Tipe Kendaraan}

Angka ekivalen (E) dari suatu beban kendaraan adalah angka yang menyatakan perbandingan tingkat kerusakan yang ditimbulkan oleh suatu lintasan beban sumbu tunggal kendaraan terhadap tingkat kerusakan yang ditimbulkan oleh suatu lintasan beban standar sumbu tunggal seberat 8,16 ton (18.000 lb). Untuk kendaraan jenis mobil dan bus hanya memiliki sumbu tunggal sehingga untuk menghitung angka ekivalen dari jenis kendaraan tersebut menggunakan rumus ekivalen tunggal yang kemudian ditotalkan sumbu tunggal bagian depan dan belakangnya. Sementara itu untuk kendaraan jenis truk memiliki sumbu tunggal dan ganda sehingga untuk menghitung angka ekivalen untuk truk menggunakan rumus ekivalen sumbu tunggal dan ganda kemudian ditotalkan. Angka ekivalen (E) masing-masing golongan beban sumbu (setiap kendaraan) dapat ditentukan berdasarkan rumus ekivalen sumbu tunggal dan ekivalen sumbu ganda berikut (contoh untuk jenis kendaraan mobil):

Angka ekivalen sumbu tunggal

$$
\begin{aligned}
\text { E Tunggal mobil }= & \left(\frac{\text { Beban Sumbu Tunggal }}{8,16}\right)^{4} \\
& =\left(\frac{1000}{8160}\right)^{4} \\
& =0.0002
\end{aligned}
$$

Angka ekivalen sumbu ganda (Apabila kendaraan memilki sumbu ganda) 
E Ganda mobil $=\left(\frac{\text { Beban Sumbu ganda }}{8,16}\right)^{4} \times 0.086$

Tabel 5. Angka Ekivalen Masing-Masing Kendaraan

\begin{tabular}{lc}
\hline \multicolumn{1}{c}{ Jenis Kendaraan } & Ekivalen (E) \\
\hline Mobil 2 ton & 0.0004 \\
Bus 5.4 ton & 0.0323 \\
Truk Kecil 2 As 8.6 ton & 0.0346 \\
Truk Besar 2 As 15 ton & 0.3553 \\
Truk Besar 3 As 25 ton & 2.1287 \\
\hline
\end{tabular}

Menentukan LEP, LEA, LET, LER

Lintas ekivalen permukaan (LEP) adalah jumlah lintas ekivalen harian rata-rata dari sumbu tunggal seberat 8,16 ton $(18.000 \mathrm{lb}$ ) pada jalur rencana yang diduga terjadi pada umur rencana (5, 10 dan 20 tahun). Hasil perhitungan LEP, LET dan LER dapat dilihat pada Tabel 6, Tabel 7 dan Tabel 8, LEP dihitung dengan menggunakan rumus (contoh untuk jenis kendaraan mobil umur rencana 5 tahun):

LEP mobil (5 tahun) $=\sum_{\mathrm{J}=1}^{\mathrm{n}} \mathrm{LHR} \times \mathrm{C} \times \mathrm{E}$

LEP mobil $(5$ tahun $)=\sum_{\mathrm{J}=1}^{\mathrm{n}} 905 \times 1.00 \times 0.0004$

LEP mobil ( 5 tahun $)=0.36$

Dimana:

$\mathrm{J} \quad=$ jenis kendaraan

C = Koefisien distribusi kendaraan

$\mathrm{E} \quad=$ Angka ekivalen

Lintas ekivalen akhir (LEA) adalah jumlah lintas ekivalen harian rata-rata dari sumbu tunggal seberat 8,16 ton ( $18.000 \mathrm{lb}$ ) pada jalur rencana yang diduga terjadi pada akhir umur rencana. LEA dihitung dengan menggunakan rumus (contoh untuk jenis kendaraan mobil umur rencana 5 tahun):

LEA mobil $(5$ tahun $)=\sum_{\mathrm{J}=1}^{\mathrm{n}} \mathrm{LHR} \times(1+\mathrm{i})^{\mathrm{UR}} \times \mathrm{C} \times \mathrm{E}$ LEA mobil (5 tahun) $=\sum_{\mathrm{j}=1}^{\mathrm{n}} 905 \times(1+0.083)^{5} \times$ $1.00 \times 0.0004$

Dimana:

$\mathrm{i}=$ Pertumbuhan lalu lintas

$\mathrm{J}=$ Jenis kendaraan

$\mathrm{C}=$ Koefisien distribusi Kendaraan

$\mathrm{E}=$ Angka ekivalen

$\mathrm{UR}=$ Umur rencana

Lintas ekivalen tengah ( LET) adalah jumlah lintas ekivalen harian rata-rata dari sumbu tunggal seberat 8,16 ton $(18.000 \mathrm{lb}$ ) pada jalur rencana yang diduga terjadi pada pertengahan umur rencana. LET dihitung dengan menggunakan rumus (contoh untuk jenis kendaraan mobil umur rencana 5 tahun):
LET mobil $(5$ tahun $)=1 / 2 \times($ LEP + LEA $)$

LET mobil $(5$ tahun $)=1 / 2 \times(0.36+0.54)$

LET mobil ( 5 tahun $)=1.45$

Lintas ekivalen rencana (LER) adalah suatu besaran yang dipakai dalam nomogram penetapan tebal perkerasan untuk menyatakan jumlah lintas ekivalen sumbu tunggal seberat 8,16 ton ( $18.000 \mathrm{lb}$ ) pada jalur rencana. LER dihitung dengan menggunakan rumus (contoh untuk jenis kendaraan mobil umur rencana 5 tahun):

$$
\begin{aligned}
& \text { LER mobil }(5 \text { tahun })=\text { LET } \times \frac{\text { UR }}{10} \\
& \text { LER mobil }(5 \text { tahun })=1.45 \times \frac{5}{10} \\
& \text { LER mobil }(5 \text { tahun })=0.22
\end{aligned}
$$

Tabel 6. LEP, LEA LET dan LER Umur Rencana 5 Tahun

\begin{tabular}{cccc}
\hline LEP & LEA & LET & LER \\
\hline 0.36 & 0.54 & 1.45 & 0.22 \\
1.16 & 1.73 & 1.44 & 0.72 \\
7.50 & 11.19 & 9.34 & 4.67 \\
54.72 & 81.52 & 68.12 & 34.06 \\
134.10 & 199.80 & 166.95 & 83.47 \\
Jumlah & & & 123.14 \\
\hline
\end{tabular}

Tabel 7. LEP, LEA LET dan LER Umur Rencana 10 Tahun

\begin{tabular}{cccc}
\hline LEP & LEA & LET & LER \\
\hline 0.53 & 1.19 & 0.86 & 0.86 \\
1.74 & 3.87 & 2.80 & 2.80 \\
11.14 & 24.73 & 17.93 & 17.93 \\
81.36 & 180.59 & 130.97 & 130.97 \\
200.09 & 444.15 & 322.12 & 322.12 \\
Jumlah & & & 474.68 \\
\hline
\end{tabular}

Tabel 8 LEP, LEA LET dan LER Umur Rencana 20 Tahun

\begin{tabular}{cccc}
\hline LEP & LEA & LET & LER \\
\hline 1.19 & 5.89 & 3.54 & 7.08 \\
3.80 & 18.93 & 11.36 & 22.72 \\
24.73 & 121.88 & 73.30 & 146.60 \\
180.49 & 889.25 & 534.87 & 1069.74 \\
440.64 & 2170.97 & 1305.80 & 2611.60 \\
Jumlah & & & 3857.74 \\
\hline
\end{tabular}

\section{Faktor Regional}

Faktor regional adalah faktor setempat, menyangkut keadaan lapangan dan iklim yang dapat mempengaruhi keadaan daya dukung tanah dasar dan perkerasan. Sesuai dengan pedoman Bina Marga 1987 seperti yang termuat pada Bab II, maka pada perencanaan tebal perkerasan ruas jalan ini dapat diambil faktor regional sebagai berikut : 
a. Berdasarkan persyaratan teknis ruas jalan dalam system jaringan

jalan primer untuk fungsi jalan kolektor (kelas I), kelandaian $6-10 \%$ ( Petunjuk Perencanaan Tebal Perkerasan Lentur Dengan Metode Analisa Komponen, Departemen Pekerjaan Umum ).

b. Persentase kendaraan berat

berdasarkan LHR rencana untuk perhitungan \% kendaraan berat untuk jenis kendaraan mobil adalah sebagai berikut, untuk hasil perhitungan \% berat kendaraan berat masing - masing jenis kendaraan dapat dilihat pada Tabel 9.

$$
\left(\frac{\mathrm{p}}{8.16}\right)^{4}=\left(\frac{5.4}{8.16}\right)^{4}=0.192
$$

Keterangan : $\mathrm{P}$ adalah beban sumbu kendaraan dan 8,16 adalah beban sumbu standar serta mobil tidak masuk dalam kategori kendaraan berat menurut Bina Marga 1987. Perhitungan selanjutnya dapat dilihat di bawah ini :

Tabel 9. Berat Masing-Masing kendaraan Berat

\begin{tabular}{lc}
\hline \multicolumn{1}{c}{ Jenis Kendaraan } & $\begin{array}{c}\text { Berat Kendaraan } \\
\text { Setelah Dibagi 8.16 }\end{array}$ \\
\hline Bus 5.4 ton & 0.192 \\
Truk 2 As 8.16 ton & 1 \\
Truk Besar 2 As 15 ton & 11.41 \\
Truk Besar 3 As 25 ton & 88.10 \\
Jumlah (nb) & 100.702 \\
\hline
\end{tabular}

Umur 5 Tahun:

$\%$ Kendaraaan Berat $(5$ tahun $)=\frac{\mathrm{nb}}{\mathrm{LHR}}$

$\%$ Kendaraaan Berat $(5$ tahun $)=\frac{100.702}{1375}$

$\%$ Kendaraaan Berat (5 tahun $)=7.32<30 \%$

Umur 10 Tahun:

$\%$ Kendaraaan Berat $(10$ tahun $)=\frac{\mathrm{nb}}{\mathrm{LHR}}$

$\%$ Kendaraaan Berat $(10$ tahun $)=\frac{100.702}{2047}$

$\%$ Kendaraaan Berat $(10$ tahun $)=4.92<30 \%$

Umur 20 Tahun:

$\%$ Kendaraaan Berat (20 tahun $)=\frac{\mathrm{nb}}{\mathrm{LHR}}$

$\%$ Kendaraaan Berat (20 tahun $)=\frac{100.702}{4540}$

$\%$ Kendaraaan Berat $(20$ tahun $)=2.22<30 \%$

Berdasarkan data Jumlah curah hujan rata-rata kabupaten Manggarai Barat tahun 2016 sebesar 117.166 ( $\mathrm{mm} /$ tahun) dan pada tahun 2017 sebesar 87.791 (mm / tahun), maka nilai proyeksi curah hujan rata-rata untuk tahun 2019 dalam persen berdasarkan data curah hujan rata -rata Kabupaten Manggarai Barat untuk tahun 2016 sampai 2017 yang dapat ditentukan berdasarkan rumus di bawah ini:
Mencari pertumbuhan curah hujan dari tahun 20162017 (i):

$$
\begin{aligned}
& \text { i } \left.(2016-2017)=\left(\left(\frac{b}{a}\right)^{\frac{1}{n}}\right)-(1)\right) \times 100 \% \\
& \left.i(2016-2017)=\left(\left(\frac{117.166}{87.791}\right)^{\frac{1}{2}}\right)-(1)\right) \times 100 \% \\
& (2016-2017)=15.52 \%=0.1552 \\
& \text { Dimana: } \\
& \text { a } \quad=\text { Nilai rata-rata tahun awal } \\
& \text { b } \quad=\text { Nilai rata-rata tahun akhir } \\
& n \quad=\text { Jumlah tahun }
\end{aligned}
$$

Proyeksi jumlah curah hujan tahun awal $2019\left(\mathrm{Ch}_{n}\right)$ :

$$
\begin{aligned}
& \mathrm{Ch}_{n}=\mathrm{Ch}_{\circ}(1+\mathrm{i})^{\mathrm{n}} \\
& \mathrm{Ch}_{n}=117.166(1+0.1552)^{2} \\
& \mathrm{Ch}_{n}=156.36 \mathrm{~mm} / \text { tahun }<190 \mathrm{~mm} / \text { tahun }
\end{aligned}
$$

Dimana:

$$
\begin{array}{ll}
\text { Chn } & =\text { Jumlah rata-rata curah hujan } \\
\text { Cho } & =\text { Jumlah curah hujan rata-rata tahun } \\
& \text { awal } \\
\mathrm{n} & =\text { jumlah tahun } \\
\mathrm{i} & =\text { Pertumbuhan lalu lintas rata-rata }
\end{array}
$$

Berdasarkan Faktor Regional, maka faktor regional yang diperoleh yaitu: Curah hujan ratarata tahun 2019 sebesar $156.36 \mathrm{~mm} /$ tahun masuk dalam kategori Iklim I < $900 \mathrm{~mm} / \mathrm{th}$, Kelandaian II $6-10 \%$, diambil FR $=1,0$.

\section{Menentukan Indeks Permukaan Pada Akhir Umur Rencana (IP)}

Berdasarkan dengan memperhatikan nilai LER (Laju Ekivalen Rencana) maka data IP dapat dilihat pada Tabel 10.

Tabel 10. Indeks Permukaan Pada Akhir Umur Rencana (IP)

\begin{tabular}{lll}
\hline Umur Rencana & LER & IP \\
\hline 5 Tahun & 123.4 & 2.0 \\
10 tahun & 474.68 & 2.0 \\
20 Tahun & 3857.74 & 2.5 \\
\hline
\end{tabular}

\section{Menentukan Indeks Permukaan Pada Awal Umur Rencana (IPo) \\ Pada penelitian ini peneliti} menggunakan lapisan permukaan Laston dengan nilai IPo $\geq 4$.

\section{Menentukan Indeks Tebal Perkerasan (ITP)} Indeks tebal perkerasan adalah suatu angka yang berhubungan dengan penentuan tebal perkerasan. Sesuai pedoman Bina Marga tahun 1987 untuk perencanaan tebal perkerasan jalan baru Berdasarkan nilai $I p=2.0$ dan Ipo $=\geq 4$ untuk umur rencana 5 tahun maka untuk mencari nilai ITP menggunakan nomogram $=3$, Berdasarkan nilai $I p=2.0$ dan $\mid \mathrm{po}=\geq 4$ untuk umur rencana 10 tahun maka untuk mencari nilai ITP menggunakan 
nomogram $=3$, Berdasarkan nilai $I p=2.5$ dan $I p o=\geq 4$ untuk umur rencana 20 tahun maka untuk mencari nilai ITP menggunakan nomogram $=1$. Maka didapat nilai ITP untuk masing - masing umur rencana yang dapat dilihat pada Tabel 11.

Tabel 11. LER, CBR, DDT dan ITP

\begin{tabular}{ccccc}
\hline $\begin{array}{c}\text { CBR } \\
\%\end{array}$ & $\begin{array}{c}\text { DDT } \\
\mathrm{kg} / \mathrm{cm}^{2}\end{array}$ & $\begin{array}{c}\text { LER } \\
\text { (Tahun) }\end{array}$ & FR & ITP \\
\hline 4.2 & 4.5 & $5=123.4$ & 1.0 & 7 \\
& & $10=474.68$ & 1.0 & 8.48 \\
& & $20=3857.74$ & 1.0 & 12.1 \\
\hline
\end{tabular}

Menetapkan Tebal Perkerasan

a. Lapisan permukaan laston ( MS 744 ) $=\mathrm{a} 1=0.40$

b. Lapis pondasi atas laston atas) ( MS 454 ) $=\mathrm{a} 2=0.26$

c. Lapis pondasi bawah batu pecah kelas $A$ CBR $100 \%=a 3=0.13$.

d. Perhitungan tebal perkerasan: $\mathrm{ITP}=\mathrm{a} 1 . \mathrm{D} 1+\mathrm{a} 2 . \mathrm{D} 2+\mathrm{a} 3 . \mathrm{D} 3$

e Tebal perkerasan untuk umur rencana 5 tahun , 10 tahun dan 20.Karena nilai CBR $4.2 \%<6 \%$ maka dilakukan stabilisasi semen setebal $20 \mathrm{~cm}$ (10 cm minimum).

Dari hasil hitungan yang dilakukan maka dapat dihitung ketebalan sebagai berikut:
LER 5 Tahun = 123.4
LER 10 tahun = 474.68
LER 20 Tahun $=\quad 3857.74$
CBR $=4.2 \%$
DDT $=4.37 \mathrm{~kg} / \mathrm{cm} 2$

Lapisan Perkerasan Permukaan dengan

Koefisen kekutan relatif

$(\mathrm{a} 1)=0.40=$ Laston (MS 744)

Lapisan Perkerasan Pondasi dengan

Koefisen kekutan relatif

$(\mathrm{a} 2)=0.26 \quad=\quad$ Laston Atas (MS 454)

Lapisan Perkerasan Pondasi Bawah dengan

Koefisen kekutan relatif

$\begin{array}{ll}(\mathrm{a} 3)=0.13 & =\quad \text { Batu Pecah Kelas } \mathrm{A} \\ (\mathrm{CBR} 70 \%) & =4\end{array}$

Tabel 12. Bina Marga 1987

\begin{tabular}{lccc}
\hline \multicolumn{1}{c}{ Lapisan } & $\begin{array}{c}\text { 5 Tahun } \\
(\mathrm{cm})\end{array}$ & $\begin{array}{c}\text { 10 Tahun } \\
(\mathrm{cm})\end{array}$ & $\begin{array}{c}\text { 20 Tahun } \\
(\mathrm{cm})\end{array}$ \\
\hline Laston & 7,5 & 7,5 & 10 \\
& & & \\
Laston Atas & 11 & 14 & 22 \\
Batu Pecah & 10 & 10 & 18.30 \\
Stabilisasi & 20 & 20 & 20 \\
Semen & & & \\
Jumlah & 48,5 & 53,5 & 70,30 \\
\hline
\end{tabular}

\section{Desain Perkerasan Metode Bina Marga} 2017

Perancangan kebutuhan lapis perkerasan lentur menggunakan Manual Desain Perkerasan Jalan 2017 memerlukan beberapa tahap penyelesaian. Adapun tahapan dari metode ini adalah:

\section{Umur Rencana Jalan}

Berdasarkan untuk jenis perkerasan lentur dengan elemen perkerasan aspal menggunakan umur rencana 20 tahun (Bina Marga, 2017).

\section{Nilai Faktor Laju Pertumbuhan Lalu Lintas} (I)

Pertumbuhan lalu lintas adalah pertambahan atau pertumbuhan lalu lintas dari tahun ke tahun selama umur rencana. Didapatkan jumlah kendaraan tahun 2017 (tahun awal) sebesar 10447 kendaraan dan pada tahun 2018 (tahun akhir) sebesar 12260 kendaraan maka didapatkan nilai pertumbuhan lalu lintas sebagai berikut:

$$
\begin{gathered}
\mathrm{i}(2017-2018)=\left(\left(\left(\frac{\mathbf{b}}{\mathbf{a}}\right)^{\frac{1}{\mathbf{n}}}\right)-(1)\right) \times 100 \% \\
\mathrm{i}=\left(\left(\left(\frac{\mathbf{1 2 2 6 0}}{\mathbf{1 0 4 4 7}}\right)^{\frac{1}{n}}\right)-(1)\right) \times 100 \% \\
\quad \mathrm{i}=8.3 \%=0.083
\end{gathered}
$$

Dimana:

$$
\begin{array}{ll}
\mathrm{a} & =\text { Jumlah kendaraan tahun awal } \\
\mathrm{b} & =\text { Jumlah kendaraan tahun akhir } \\
\mathrm{n} & =\text { Jumlah tahun }
\end{array}
$$

Nilai faktor pengali pertumbuhan lalu lintas Untuk menghitung pertumbuhan lalu lintas selama umur rencana dapat dihitung sebagai berikut:

Umur 5 Tahun:

$$
\begin{aligned}
& \mathrm{R} 5=\frac{(1+0.01 \times i)^{U R}-1}{0.01 i} \\
& \mathrm{R} 5=\frac{(1+0.01 \times 0.083)^{5}-1}{0.01 \times 0.083} \\
& \mathrm{R} 5=5.008
\end{aligned}
$$

Umur 10 Tahun:

$$
\begin{aligned}
& \mathrm{R} 10=\frac{(1+0.01 \times i)^{U R}-1}{0.01 i} \\
& \mathrm{R} 10=\frac{(1+0.01 \times 0.083)^{10}-1}{0.01 \times 0.083} \\
& \mathrm{R} 10=10.037
\end{aligned}
$$

Umur 20 Tahun:

$$
\begin{aligned}
& U \text { R2 } 0=\frac{(1+0.01 \times i)^{U R}-1}{0.01 i} \\
& \text { R20 }=\frac{(1+0.01 \times 0.083)^{20}-1}{0.01 \times 0.021} \\
& \text { R20 }=20.158
\end{aligned}
$$




\section{Judul Artikel Jurnal 35 \\ Nama Penulis ${ }^{1 *}$, Nama Penulis ${ }^{2}$, dan Nama Penulis ${ }^{3}$ \\ ESAL5 $=($ (jenis kendaraan LHRT $\times$ VDF5 $) \times 365 \times$ $\mathrm{DD} \times \mathrm{DL} \times \mathrm{R}$ \\ $=(905 \times 0,2) \times 365 \times 0,5 \times 1 \times 5.008$}

Dimana:

$\mathrm{i}=$ Pertumbuhan lalu lintas

UR = Umur Rencana

Nilai faktor distribusi arah (DD) dan faktor distribusi lajur (DL)

Beban lalu lintas pada lajur rencana dinyatakan dalam kumulatif beban gandar standar (ESAL) dengan memperhitungkan faktor distribusi arah (DD) dan faktor distribusi lajur kendaraan niaga (DL). Untuk jalan Labuan Bajo-Lembor yang menggunakan sistem dua arah, faktor distribusi arah (DD) umumnya diambil 0,50 atau $50 \%$ tiap lajur untuk satu jalur. Sedangkan untuk faktor distribusi lajur kendaraan niaga (DL), jalan Labuan BajoLembor bernilai 1 adalah $100 \%$ karena jumlah lajur per arah adalah 1 sesuai dengan perencanaan dalam penelitian ini.

\section{Perkiraan Faktor Ekivalen Beban (Vehicle Damage Factor)}

Untuk menghitung faktor kerusakan jalan atau yang biasa disebut dengan Vehicle Damage Factor (VDF) perlu diperoleh gambaran tentang beban sumbu kendaraan dan konfigurasi sumbu kendaraan yang ada. Pada Manual Desain Perkerasan Jalan Lentur 2017, VDF dibedakan menjadi VDF4 dan VDF5 sehingga nantinya akan membedakan hasil Beban sumbu standar kumulatif atau Cumulative Equivalent Single Axle Load (CESAL) menjadi CESAL4 dan CESAL5. CESAL4 digunakan untuk menentukan pemilihan jenis perkerasan sedangkan CESAL5 digunakan untuk menentukan tebal perkerasan lentur berdasarkan bagan desain yang disediakan Manual Desain Perkerasan Jalan Lentur 2017. Untuk menentukan nilai VDF dapat diklasifikasikan berdasarkan jenis kendaraan yang dapat kita lihat Tabel 13.

Tabel 13. Nilai VDF 4 dan VDF 5 Rencana

\begin{tabular}{cccc}
\hline Jenis kendaraan & Kode & VDF 4 & VDF 5 \\
\hline Bus Sedang & $5 \mathrm{a}$ & 0.3 & 0.2 \\
Truk Kecil 2 As & $6 \mathrm{a}$ & 0.55 & 0.55 \\
Truk Besar 2 As & $6 \mathrm{~b}$ & 4 & 5.1 \\
Truk Besar 3 As & $7 \mathrm{a}$ & 4.7 & 6.4 \\
\hline
\end{tabular}

Dari beberapa hasil data-data yang disampaikan, maka dapat dicari rencana jumlah kendaraan dalam periode umur rencana. Berikut ini adalah contoh perhitungan kendaraan umur rencana 5 tahun untuk masing-masing jenis kendaraan:

ESAL4 $=($ (jenis kendaraan LHRT $\times$ VDF4 $) \times 365$ $\times$ DD $\times$ DL $\times \mathrm{R}$

$=(905 \times 0,3) \times 365 \times 0,5 \times 1 \times 5.008$
Untuk data tahun berikutnya ditampilkan dalam bentuk tabel yaitu Tabel 14 .

Tabel 14. Nilai CESA 4 dan CESA 5 dan

Tebal Perkerasan Umur Rencana

\begin{tabular}{ccc}
\hline UR & CESA 4 & CESA 5 \\
\hline 5 & $949.832,922$ & $1.200 .166,574$ \\
10 & $2.829 .815,924$ & $3.583 .686,216$ \\
20 & $12.632 .567,563$ & $15.939 .104,462$ \\
\hline
\end{tabular}

Tabel 15. Manual Desain Perkerasan jalan 2017

\begin{tabular}{cccc}
\hline Lapisan & 5 Tahun & 10 Tahun & 20 Tahun \\
\hline AC-WC & 4 & 4 & 4 \\
AC-BC & 6 & 6 & 6 \\
AC -Base & 0 & 7 & 14,5 \\
LPA KIs. & 40 & 30 & 30 \\
A & & & \\
$\begin{array}{c}\text { Stabilisa } \\
\text { si Semen }\end{array}$ & 20 & 20 & 20 \\
Jumlah & 70 & 67 & 74 \\
\hline
\end{tabular}

\section{Menentukan tipe perkerasan}

Pemilihan jenis perkerasan akan bervariasi sesuai dengan estimasi lalu lintas dan umur rencana. Berdasarkan hasil beban sumbu standar kumulatif atau Cummulative Equivalent Single Axle Load (CESAL) yang diperoleh sebelumnya, maka dapat dilakukan penentuan jenis perkerasan.

a. Untuk Umur Rencana 5 Tahun dengan CESAL 4 sebesar 949.832,992 ESAL jenis perkerasan yang didapat adalah AC WC modifikasi dengan CTB dan berdasarkan nilai CESAL 5 sebesar 1.200.166,574. Untuk Umur Rencana 10 Tahun dengan CESAL 4 sebesar 2.829.815,924 dan CESAL 5 sebesar $3.583 .686,216$ jenis perkerasan jenis perkerasan yang didapat adalah AC WC modifikasi dengan CTB dan berdasarkan nilai CESAL 5 didapat tebal perkerasan untuk Umur Rencana 20 Tahun dengan CESAL 4 sebesar 12.632.567,563 dan CESAL 5 sebesar jenis perkerasan jenis perkerasan yang didapat adalah AC WC modifikasi dengan CTB dan berdasarkan nilai CESAL 5 sebesar 15.939.104,462

b. Karena nilai CBR $4.2 \%<6 \%$ maka dilakukan stabilisasi semen setebal $20 \mathrm{~cm}$ (10 cm minimum). Karena telah dilakukan stabilisasi maka CBR tanah dasar yang semula $4.2 \%$ meningkat. 


\section{PENUTUP}

\section{Kesimpulan}

Berdasarkan perhitungan metode Bina Marga 1987 didapatkan tebal perkerasan jalan untuk umur rencana 5 tahun lapisan permukaan (laston) $7.5 \mathrm{~cm}$, lapisan pondasi atas (laston atas) $11 \mathrm{~cm}$ dan lapisan pondasi bawah (batu pecah) $10 \mathrm{~cm}$; untuk umur rencana 10 tahun lapisan permukaan (laston) $7.5 \mathrm{~cm}$, lapisan pondasi atas (laston atas) 16 $\mathrm{cm}$ dan lapisan pondasi bawah (batu pecah) 10 $\mathrm{cm}$ dan untuk umur rencana 20 tahun lapisan permukaan (laston) $10 \mathrm{~cm}$, lapisan pondasi atas (laston atas) $22 \mathrm{~cm}$ dan lapisan pondasi bawah (batu pecah) $18.30 \mathrm{~cm}$. Sedangkan berdasarkan perhitungan metode Manual Desain Perkerasan Jalan 2017 didapatkan tebal perkerasan jalan untuk umur rencana 5 tahun lapisan permukaan (AC-WC) $4 \mathrm{~cm}$, Lapisan Permukaan antara (AC-BC) $6 \mathrm{~cm}$, lapisan pondasi atas (Ac Base) $0 \mathrm{~cm}$ dan lapisan pondasi bawah (LPA Kelas A) $40 \mathrm{~cm}$; untuk umur rencana 10 tahun lapisan permukaan (AC-WC) $4 \mathrm{~cm}$, Lapisan Permukaan antara (AC-BC) $6 \mathrm{~cm}$, lapisan pondasi atas (Ac Base) $7 \mathrm{~cm}$ dan lapisan pondasi bawah (LPA Kelas A) $30 \mathrm{~cm}$ dan untuk umur rencana 20 tahun lapisan permukaan (AC-WC) $4 \mathrm{~cm}$, Lapisan Permukaan antara (AC-BC) $6 \mathrm{~cm}$, lapisan pondasi atas (Ac Base) $14.5 \mathrm{~cm}$ dan lapisan pondasi bawah (LPA Kelas A) $30 \mathrm{~cm}$. Berdasarkan tebal perkerasan kedua metode maka dapat disimpulkan bahwa Jika dilihat dari jumlah ketebalan seluruh lapisan dari masing masing umur rencana 5, 10 dan 20 tahun metode Manual Desain Perkerasan Jalan 2017 jauh lebih tebal jika dibandingkan dengan metode Bina Marga 1987, hal ini dikarenakan perbedaan batas minimum ketebalan dari kedua metode. Sehingga metode yang jauh lebih ekonomis (memiliki ketebalan yang kecil) untuk perencanaan jalan baru adalah metode Bina Marga 1987.

\section{Saran}

Sesuai dengan kesimpulan yang diperoleh di atas, maka ada beberapa hal yang dapat dihasilkan saran sebagai berikut:

1. Agar konstruksi dapat bertahan/mencapai umur rencana hendaknya dilakukan kegiatan perawatan secara rutin, sehingga dapat meminimalkan terjadinya kerusakan pada konstruksi.

2. Pada pelaksanaan di lapangan hendaknya tetap berpedoman pada spesifikasi teknis yang ada sehingga kesalahan pada pelaksanaan dapat ditekan sekecil mungkin.

3. Untuk lebih mendukung hasil rencana yang lebih efektif dan efesien, maka perlu dilakukan pengujian dan pemeriksaan nilai
CBR setiap material yang digunakan dan sebaiknya dilengkapi dengan perhitungan Rancangan Anggaran Biaya (RAB).

4. Untuk penelitian selanjutnya dapat dilakukan perbandingan dengan menggunakan metode berbeda seperti AASHTO, Bina Marga dan metode lainya.

\section{UCAPAN TERIMAKASIH}

Pada kesempatan ini penulis mengucapkan terimakasih kepada pembimbing penelitian ini yaitu kepada Bapak Hermansyah, S.T., M.Sc. selaku pembimbing pertama dan Bapak Dedy Dharmawansyah, S.T., M.T. selaku pembimbing kedua. Penulis juga mengucapkan terimakasih kepada kedua orang tua yang selalu mendukung baik dari segi moril maupun materi sehingga penelitian ini dapat terselesaikan dengan sesuai harapan.

\section{DAFTAR PUSTAKA}

AASHTO. (1993). Guide for Design of Pavement Structures 1993. American Association of State Highways and Transportation Officials, Washington, D.C, USA.

Bachnas. (2009). Penyebab Kerusakan Jalan. http://www.google.com/Penyebab Kerusakan Jalan diakses 31 maret 2019.

Departemen Pekerjaan Umum, Direktorat Jenderal Bina Marga. (1987), Petunjuk Perencanaan Tebal Perkerasan Lentur Jalan Raya Dengan Metode Analisa Komponen. (SKBI - 2.3.25. 1987. PT. Bina Karya \& Swe Road .

Jehadus, S. (2019). Analisis Faktor Penyebab Kerusakan Jalan Raya Lintas Labuan Bajo Lembor Flores Nusa Tenggara Timur. Skripsi. Universitas 17 Agustus 1945 Surabaya. Surabaya.

Mamari, R. L. P. (2017). Studi Perencanaan Perkerasan Lentur Jalan Raya Dengan Standar Bina Marga Pada Ruas Jalan Sentani-Warumbain Km 41+000-Km 61+000 $(20 \mathrm{Km})$. Skripsi. Institut Teknologi Malang. Malang.

Menteri Pekerjaan Umum. (2017). Manual Perkerasan Jalan (Revisi Juni 2017) Nomor 04/SE/Db/2017. Jakarta: Direktorat Jenderal Bina Marga.

Oetomo, W. (2013). Alternatif Lain Analisis struktur Jalan Perkerasan Lentur Pada Pembangunan Jalan Lingkar Selatan Kota Pasuruan. Ekstrapolasi Jurnal Teknik Sipil UNTAG Surabaya. Surabaya. 6 (01). 118136.

Presiden Republik Indonesia. No 38 Tahun (2004). Undang - Undang Tentang Jalan Tahun 2004. Lembaran Negara RI Tahun 2004. No. 4.

Puspito, I. H. (2008). Perencanaan Perkerasan Jalan. Makalah Dapartemen Teknik Sipil. Universitas Pancasila. Jakarta. 
Sukirman, S. (1999). Perkerasan Lentur (Flexible Pavement) Jalan Raya. Penerbit Nova. Bandung

Sukirman, S. (2003). Perkerasan Jalan Raya. Penerbit Nova. Bandung.

Sumarsono, S. \& Gultom, H. J. H. (2018). Perbandingan Analisa Perkerasan Metode Bina Marga Revisi Juni 2017 dan AASHTO 1993 (Studi Kasus Pada Pekerjaan Rencana Preservasi Ruas Jalan Jatiberang - Langut TA 2017). Jurnal Online Institut Teknologi Nasional. 4 (03). 60-71. 